\title{
Patent ductus arteriosus closure using an Amplatzer ventricular septal defect closure device in adulthood
}

\author{
Loua Hattach, Kawtar Afrikh, Nadia Fellat, Rokya Fellat
}

Cardiology Department A, Hopital Ibn Sina, Rabat, Morocco

ARTICLE INFO

Article history:

Submitted: 10. 1. 2019

Accepted: 10. 4. 2019

Available online: 10. 2. 2020

Klíčová slova:

Amplatzův septální okluder

Dospělá osoba

Patent ductus arteriosus

Perkutánní metoda uzavření
SOUHRN

Termínem otevřená tepenná dučej (patent ductus arteriosus, PDA) se označuje trvalé spojení mezi sestupnou hrudní aortou a plicnicí, které vzniká, pokud ve fetálním období nedojde k normálnímu fyziologickému uzavření dučeje. Jedná se o poměrně častou vrozenou srdeční vadu.

Hlavní metodou léčby je uzavření PDA, které lze provést bud' chirurgicky, nebo perkutánně. V posledních 20 letech se prokázala účinnost i bezpečnost katetrizačního postupu; pro tento účel byla vyvinuta řada zařízení, která jsou dnes k dispozici.

Tento článek přináší popis katetrizačního uzavření PDA u 18leté pacientky s př́ínaky připomínajícími velkou PDA. I když jsme původně uvažovali o uzavření PDA Amplatzovým okluderem, nakonec jsme se rozhodli pro použití Amplatzova septálního okluderu (ventricular septal defect [VSD] Amplatzer occluder).

(c) 2020, ČKS
Keywords:

Adult

Patent ductus arteriosus

Percutaneous closure

Ventricular septal defect device occlude

\section{ABSTRACT}

Patent ductus arteriosus (PDA) is a persistent communication between the descending thoracic aorta and the pulmonary artery that results from failure of normal physiologic closure of the fetal ductus. It is one of the more common congenital heart defects.

The PDA closure is the main treatment and can be surgical or percutaneous. The trancatheter approach proved its efficacy and safety all over the past 20 years and a variety of devices have been developed and are now available. This report describes a transcatheter closure of a PDA on an 18-year-old girl with features suggestive of a large PDA. While we intended to close the PDA using an Amplatzer device occluder (ADO), we changed our approach and used a ventricular septal defect (VSD) Amplatzer occluder instead.

\section{Introduction}

The patent ductus arteriosus (PDA) is a vascular structure that connects the proximal descending aorta to the roof of the main pulmonary artery near the origin of the left pulmonary artery. The PDA normally closes spontaneously after birth. Persistent patency few weeks after birth represents a congenital malformation. The PDA closure is the main treatment and can be surgical or percutaneous. The transcatheter approach proved its efficacy and safety all over the past 20years and a variety of devices have been developed and are now available.

This report describes our experience with transcatheter closure of a PDA with a bizarre configuration on a 18-year-old girl with features suggestive of a large PDA. While we intended to close the PDA using an Amplatzer device occluder (ADO), we changed our approach and used a ventricular septal defect (VSD) Amplatzer occluder instead.

\section{Case report}

A 18-year-old girl presented to our cardiology department for NYHA class III dyspnea. The product of an uncomplicated term delivery, her childhood medical history were unremarkable. Physical examination revealed a grade 2/6 continuous cardiac murmur in the upper left sternal border, and no cyanosis or clubbing. A chest X-ray showed an enlarged pulmonary trunk without cardiomegaly. The electrocardiogram showed no significant findings. The 
transthoracic echocardiogram revealed a large PDA 10 $\mathrm{mm} \times 7 \mathrm{~mm}$ with continuous flow and left-to-right shunt with no chamber dilatation. The patient was diagnosed as a PDA case and we planned for a percutaneous closure with an Amplatzer device (Fig. 1).

\section{Procedure}

Right femoral arterial and venous accesses were obtained using $5 \mathrm{~F}$ and $7 \mathrm{~F}$ sheaths. PDA was visualized by a descending aortogram passing a pigtail catheter via femoral artery in lateral view. The PDA shape corresponds to Krinchenko type $\mathrm{F}$ measuring $9.4 \mathrm{~mm}$ at the aortic side and 7.8 at the pulmonary artery end. The measures revealed that the TTE underestimated the size of the PDA and we decided to use a VSD device. A $10 \mathrm{~mm}$ mVSD Amplatzer occluder was then advanced to the site of the PDA through a $7 \mathrm{Fr}$ torque delivery system. Firstly, only the retention skirt of the device was deployed and pulled firmly against the aortic orifice of the PDA. Check descending aortogram was done using pigtail catheter to see the well-seated position of the device into the aortic ampulae. Then, we deployed the device securely in the patent ductus arteriosus while applying slight tension. Post deployment a second check aortogram with pigtail catheter was performed and there was no trace of residual shunt of the ductus and no aortic obstruction or embolism. The PDA has been closed successfully (Figs 2-4).

\section{Discussion}

The patent ductus arteriosus is a remnant of the distal left sixth aortic arch that connects the proximal descending aorta to the main pulmonary artery near the origin of the left pulmonary artery. ${ }^{1}$ The ductus is normally closed $48 \mathrm{~h}$ after birth otherwise it results in patent ductus arteriosus.

The closure remains the definitive therapy and can be surgical or percutaneous. The transcatheter closure technique is preferred in most centers except for very large shapes which need surgical closure. ${ }^{2}$

The percutaneous closure technique for PDA was first described by Portsmann et al. $^{3}$ who used a conical Ivalon

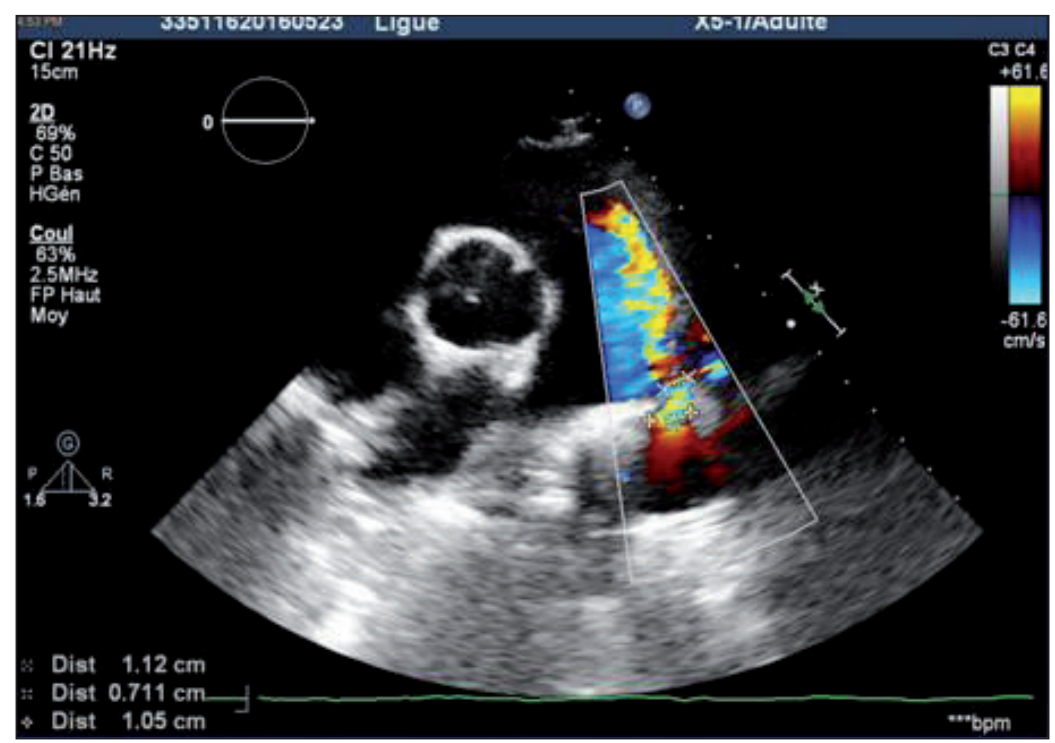

Fig. 1 - Transthoracic echocardiography (TTE) image showing the PDA
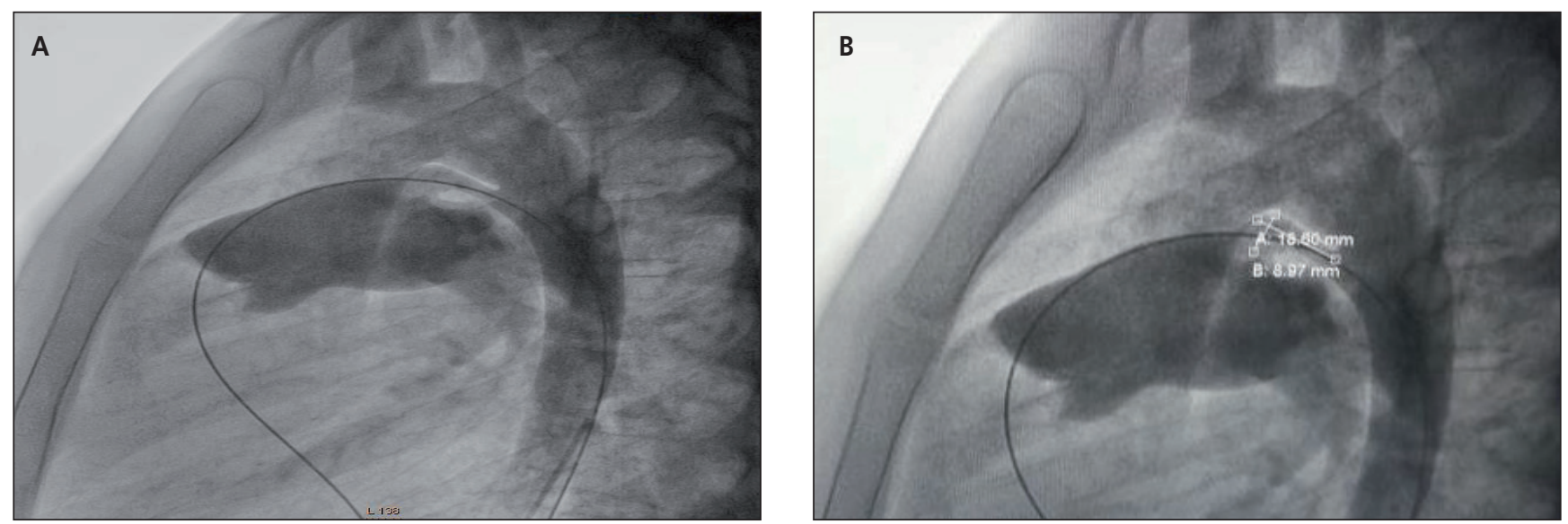

Fig. 2 - (A) and (B): Aortography in lateral view profiling the shape and size of the PDA 


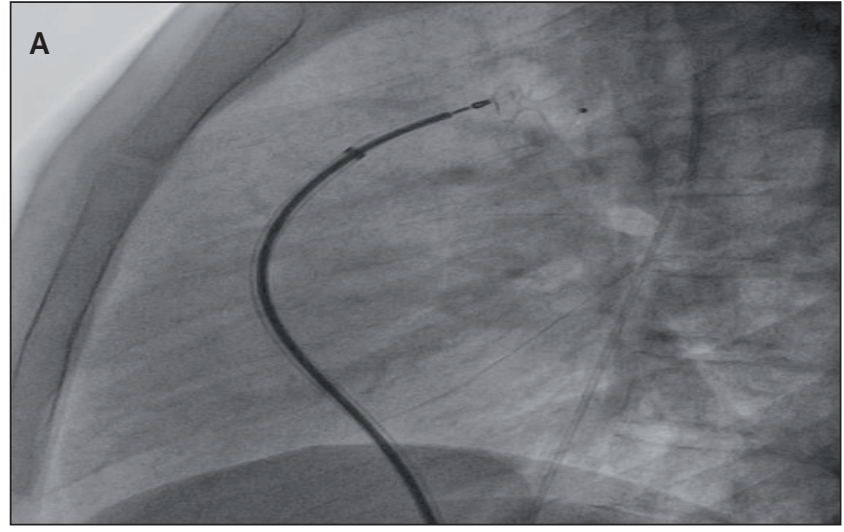

Fig. 3 - (A) and (B): Deployment of the mVSD device closing the PDA

plug in 1967, followed by Rashkind and Cuaso 4 who used an umbrella-type device in 1979.

Nowadays many new devices are available but the percutaneous closure using the ADO remains an effective and safe therapy for the majority of patients with PDA. By describing a useful angiographical classification, Krichenko et al. ${ }^{5}$ influenced the technique of catheter occlusion. Indeed thanks to this classification, we were able to use an mVSD instead of an ADO in our case.

The Amplatzer mVSD occluder (AGA Medical Corp.) is made of nitinol wire. It is a self-expandable device consisting of two flat disks that are linked via a central connecting waist whose diameter determines the size of the device.

The two disks are $4 \mathrm{~mm}$ larger than the connecting waist. Dacron fabric is incorporated into each disk to enhance thrombosis. Depending on the size of the device, It requires a $6 \mathrm{~F}$ to $9 \mathrm{~F}$ sheath for delivery, available from 4 to $18 \mathrm{~mm}$. Whereas the ADO II occluder has a narrower waist, the septal occluder provides a better approximation to the PDA wall with its wider waists. For the same reason, the ADO II may have resulted in a residual shunt when used on a patient similar to ours, given the short length and larger diameter of the PDA. Furthermore, double discs reduce the risk of embolization and have been shown to be effective on patients with elevated pulmonary pressures. ${ }^{6}$ Successful PDA closures using a VSD occluder on two patients were reported by Atiq et al. ${ }^{7}$ in a trial to assess the efficacy of newer PDA closure devices. The double disk of the VSD device and the waist may be considered in the future development of devices for the occlusion of large PDAs for adult patients.

\section{Conclusion}

The transcatheter PDA closure remains the procedure of choice in most cases. Different techniques using different devices are available. Coils and ADOs are mainly used in PDAs. PDAs with very large diameters and ambiguous shapes are not always simply closed with the ADOs but the real challenge remains in preterm and low body weight infants.

A new generation device is expected which will improve the transcatheter approach. It should target more patients and comfort its status as being a technical standard for PDAs closures.
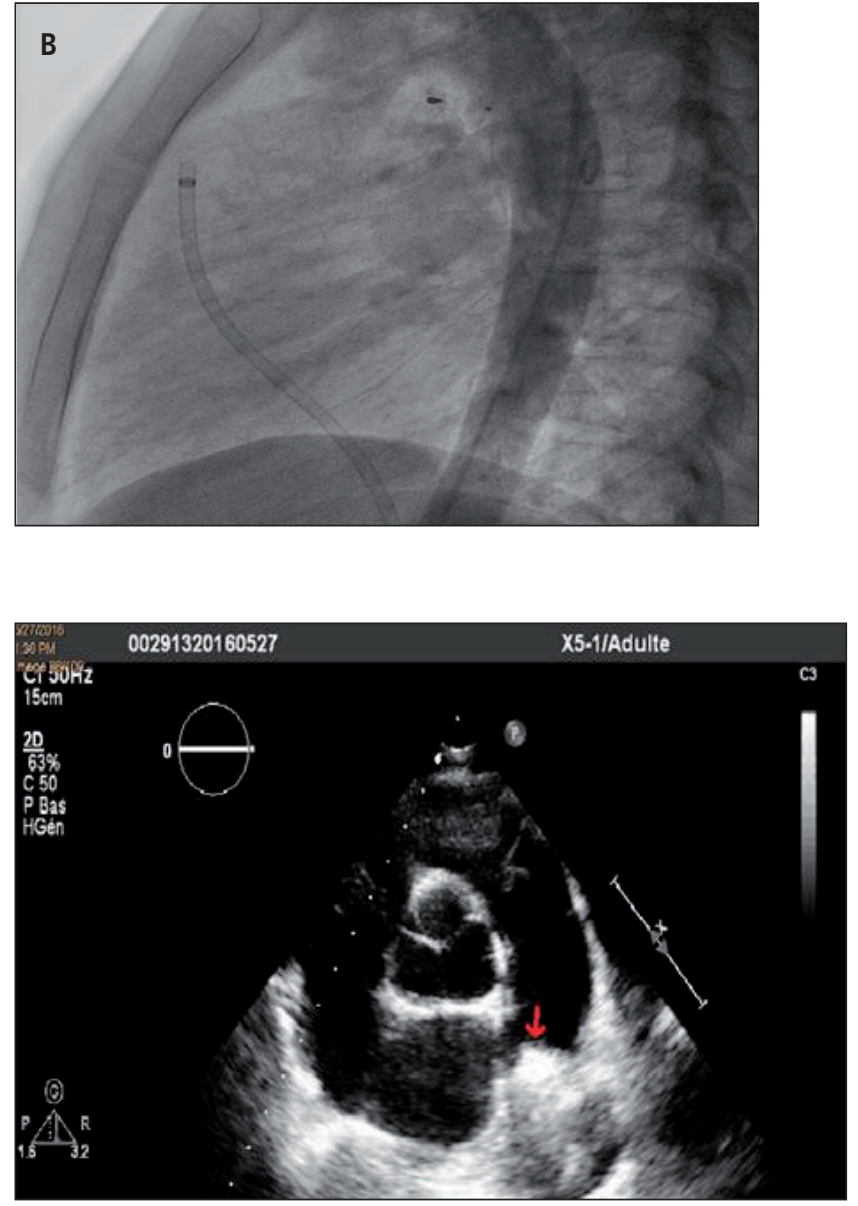

Fig. 4 - TTE image showing a successful closure of the PDA with the mVSD device without any residual shunt

Other congenital heart disorders as ASD secondum or VSD muscular are now treated by percutaneous closure which is available in our center.

\section{Conflict of interest}

The authors declare no conflict of interest.

\section{References}

1. Thanopoulos BD, Brili SD, Toutouzas PK. Patent ductus arteriosus and aortopulmonary window. In: Gatzoulis MA, Webb GD, Daubeney PEF (Eds.). Diagnosis and Management of Adult Congenital Heart Disease. 2nd edition. London, Elsevier, 2010:256-260.

2. Garson A Jr, Bricker JT, Fisher DJ, Neish SR, et al. The Science \& Practice of Pediatric Cardiology, 2nd edition, volume I. Baltimore: Williams \& Wilkins, 1998:1181-1182.

3. Portsmann W, Wierny L, Warnke H. Closure of persistent ductus arteriosus without thoracotomy. Ger Med Monthly 1967;12:259-261.

4. Rashkind WJ, Cuaso CC. Transcatheter closure of a patent ductus arteriosus: Successful use in a $3.5-\mathrm{kg}$ infant. Pediatr Cardiol 1979;1:3-7.

5. Krichenko A, Benson LN, Burrows $P$, et al. Angiographic classification of the isolated, persistently patent ductus arteriosus and implications for percutaneous catheter occlusion. Am J Cardiol 1989;63:877-880.

6. Fernando R, Koranne K, Loyalka P, et al. Patent ductus arteriosus closure using an amplatzer TM ventricular septal defect closure device. Exp Clin Cardiol 2013;18:e50-e54.

7. Atiq M, Aslam N, Kazmi KA. Transcatheter closure of small-tolarge patent ductus arteriosus with different devices: Queries and challenges. J Invasive Cardiol 2007;19:295-298. 